\title{
LATIHAN BEBAN : SEBUAH METODE LATIHAN KEKUATAN
}

Oleh: Suharjana

Dosen Jurusan Pendidikan Kesehatan dan Rekreasi FIK UNY

\section{Abstrak}

Para pakar olahraga telah meyakini bahwa untuk membangun kekuatan otot, metode yang efektif adalah dengan menggunakan latihan beban (weight training), karena dengan metode ini intensitas pembebanan bisa terukur dan bisa diatur dengan mudah dan tepat, disesuaikan dengan tujuan latihan yang diinginkan. Untuk menyusun program latihan beban, seorang pelatih harus bisa menjawab pertanyaan- pertanyaan sebagai berikut: berapa beban yang harus diangkat, berapa set latihan harus diselesaikan, berapa repetisi yang harus dilakukan, berapa kali latihan dalam seminggu, berapa menit harus istirahat diantara-set-set latihan, bentuk latihan apa saja yang cocok untuk dilatihkan. Permasalahan yang muncul dilapangan adalah masih sering ditemukan para pelatih kurang menguasai metode latihan beban dengan baik. Oleh karena itu jika ingin menggunakan metode latihan beban pelatih harus benar-benar memahami bagaimana meramu latihan ini menjadi latihan yang efektif, terukur sesuai kaidah-kaidah latihan. Sebagai bentuk sumbangan pemikiran bagi dunia kepelatihan, maka makalah ini disusun untuk menjelaskan metode latihan kekuatan, karena itu makalah ini memuat tulisan yang berupa: pengertian kekuatan otot, macam-macam kekuatan, tipe latihan kekuatan, prinsip-prinsip latihan, menyusun program latihan, keseimbangan latihan, sistem latihan, contoh progam latihan dan fase latihan. 
Berdasarkan pembahasan, maka dapat ditarik kesimpulan sebagai berikut: 1) latihan yang cocok untuk mengembangkan kekuatan otot adalah dengan latihan beban, 2) latihan didahului dengan pemanasan menyeluruh, kemudian diikuti mengangkat beban ringan, 3) menerapkan prinsip overload. Prinsip ini merupakan prinsip dominan yang akan menentukan hasil latihan, 4) repetisi antara 8-12 RM untuk setiap latihan. Setiap latihan dilakukan selama 3 set, dengan istirahat antar set 2-5 menit, 5) agar perkembangan otot tidak berat sebelah pilihlah latihan dengan memilih gerakan untuk otot agonis dan untuk antagonis, 6) perhatikan cara pernafasan. Keluarkan nafas pada saat mengangkat beban, dan mengambil nafas pada saat menurunkan beban, 7) pilih dan lakukan gerakan dengan benar, 8) latihan dilakukan 3 kali dalam satu minggu, dengan diselingi satu hari istirahat, 9) Setiap kali latihan sebaiknya tidak lebih dari 12 bentuk latihan, 10) setiap akhir sesi latihan diakhiri dengan latihan peregangan statis dan relaksasi

Kata Kunci : Weight training, Strength training.

Kekuatan otot merupakan salah satu unsur fisik penting yang harus dimiliki oleh setiap orang, karena dengan kekuatan otot yang dimiliki seseorang dapat berjalan, berlari, mengangkat atau menahan beban guna memperlancar pekerjaaan sehari-hari. Karena itu tanpa didukung oleh kekuatan otot yang baik, orang tidak akan mampu bekerja dengan baik pula. Jika seseorang mempunyai otot yang kuat akan membuat kerja otot-otot sehari-hari menjadi lebih efisien. Otot-otot yang tidak terlatih karena suatu sebab, misalnya karena sakit, otot akan menjadi lemah bahkan bisa semakin kecil (artrophi).

MEDI KORA Vol.III, No 1, April 2007:80-101 
Dalam dunia olahraga, kekuatan otot hampir pasti selalu dibutuhkan oleh setiap atlet dalam berbagai cabang olahraga, oleh karena itu upaya peningkatan kekuatan otot harus menjadi perhatian yang serius bagi setiap pelatih, agar anak latihnya bisa memiliki kondisi fisik yang prima, sehingga bisa mendukung pencapaian prestasi olahraga, karena prestasi olahraga merupakan aktualisasi dari berbagai unsur, seperti kondisi fisik, kemampuan teknik, penguasaan taktik dan kematangan mental. Sebagai missal seorang pemain bulu tangkis selain menguasai teknik dan taktik yang baik, ia juga harus memiliki kekuatan otot lengan yang baik agar smashnya bagus.

Kekuatan otot adalah unsur komponen kondisi fisik yang sangat penting dalam meningkatkan kondisi fisik secara keseluruhan karena: 1) kekuatan merupakan daya penggerak setiap aktivitas fisik, 2) kekuatan memegang peranan penting dalam melindungi otot dari kemungkinan cidera, 3) latihan kekuatan dapat membantu membentuk tubuh ideal, 4) dengan kekuatan dapat memperkuat persendian.

Menurut Bompa (2000:317) kekuatan otot merupakan unsur fisik dasar yang bisa membantu pengembangan unsur fisik lain, terutama pengembangan dayatahan otot, maximum strength, power dan maximum speed, dan agility.

Untuk memperoleh kekuatan otot yang baik, atlet harus melakukan latihan yang teratur, kontinyu dan maju berkelanjutan. Latihan adalah merupakan penerapan dari suatu perencanaan yang bertujuan untuk meningkatkan kemampuan berolahraga yang berisi materi, metode dan aturan pelaksanaan sesuai dengan tujuan hendak dicapai. Dengan demikian 
latihan merupakan proses perubahan ke arah yang lebih baik, yang bertujuan untuk meningkatkan kualitas olahragawan, karena itu agar latihan bisa efektif perlu dicarikan metode latihan yang baik dan tepat.

Para pakar olahraga telah meyakini bahwa untuk membangun kekuatan otot, metode yang efektif adalah dengan menggunakan latihan beban (weight training), karena dengan metode ini intensitas pembebanan bisa terukur dan bisa diatur dengan mudah dan tepat, disesuaikan dengan tujuan latihan yang diinginkan. Menurut Fox (1984) bahwa program latihan peningkatan kekuatan otot yang efektif adalah, program latihan dengan memakai beban (weight training).

Untuk menyusun program latihan beban, seorang pelatih harus bisa menjawab pertanyaan- pertanyaan sebagai berikut: berapa beban yang harus diangkat, berapa set latihan harus diselesaikan, berapa repetisi yang harus dilakukan, berapa kali latihan dalam seminggu, berapa menit harus istirahat diantara-set-set latihan, bentuk latihan apa saja yang cocok untuk dilatihkan. Permasalahan yang muncul dilapangan adalah masih sering ditemukan para pelatih kurang menguasai metode latihan beban dengan baik.

Oleh karena itu jika ingin menggunakan metode latihan beban pelatih harus benar-benar memahami bagaimana meramu latihan ini menjadi latihan yang efektif, terukur sesuai kaidah-kaidah latihan. Sebagai bentuk sumbangan pemikiran bagi dunia kepelatihan, maka makalah ini disusun untuk menjelaskan metode latihan kekuatan, karena itu makalah ini memuat tulisan yang beupa: pengertian kekuatan otot, macam-macam kekuatan, tipe latihan kekuatan, prinsip-prinsip latihan, menyusun program latihan,

MEDIKORA Vol.III, No 1, April 2007:80-101 
keseimbangan latihan, sistem latihan, contoh progam latihan dan fase latihan.

\section{PENGERTIÁN KEKUATAN OTOT}

Kekuatan adalah gaya maksimum yang dapat dihasilkan oleh otot atau sekelompok otot (Wilmore dan Costill, 1994: 68). Menurut Kent (1994: 427) kekuatan adalah kemampuan menggerakkan tenaga untuk mengatasi beban. Kekuatan adalah kapasitas sebuah otot yang mempergunakan tenaga (force) untuk melawan tahanan (Boosey, 1980:16). Kekuatan otot adalah kemampuan untuk mengeluarkan tenaga secara maksimal dalam satu usaha (Baechle dan Groves, 1997: 7)

Dari beberapa pendapat tersebut terdapat unsur persamaan yaitu adanya tenaga untuk melawan beban, karena itu dapat disimpulkan bahwa yang dimaksud kekuatan adalah kemampuan otot atau sekelompok otot untuk menahan atau melawan beban dalam satu kali repetisi maksimal.

Kekuatan otot dipengaruhi oleh beberapa faktor. Menurut Sharkey (2003: 16) faktor-faktor yang dapat menentukan kekuatan otot adalah :

a) Ukuran otot. Besar kecilnya ukuran otot akan berpengaruh terhadap kekuatan otot. Semakin besar serabut otot seseorang akan semakin kuat pula dalam mengangkat beban. Ukuran besar dan panjang otot dapat dipengaruhi oleh bawaan. Namun demikian pembesaran otot dapat disebabkan oleh luasnya serabut otot oleh akibat latihan.

b) Jenis Kelamin. Latihan kekuatan akan lebih memberi keuntungan pada laki-laki dari pada perempuan. Hal ini disebabkan oleh perkembangan 
otot menurut jenis kelamin. Pada awal perkembangan sebelum memasuki masa puber perkembangan kekuatan otot laki-laki dan wanita sama, tetapi setelah memasuki masa puber anak laki-laki mulai memiliki ukuran otot lebih besar dari wanita. Sampai usia 12-14 tahun kekuatan laki-laki dan wanita sama, setelah itu laki-laki berkembang lebih kuat. Hal ini disebabkan oleh hormon testosteron pada laki-laki yang meningkat 10 kali lebih banyak dari wanita. Testosteron adalah anabolik steroid yang membantu otot tumbuh membesar.

c) Umur. Kekuatan otot pada laki-laki mencapai puncak pada umur 20-an, dan menurun perlahan-lahan hingga umur 60 tahun atau lebih. Setelah itu tingkat penurunannya menjadi lebih cepat. Namun penurunan ini bisa dihambat jika kekuatan otot selalu dipertahankan dengan latihan, bahkan jika latihan teratur atau kekuatan selalu digunakan maka kekuatan bisa dipertahankan sampai usia 60-an. Sebagian para juara angkat berat mencapai puncak prestasi pada usia 40-an. Petinju kelas berat George Foreman di tahun 2000-an masih bisa juara tinju kelas berat pada usia lebih dari 40 tahun. Para mekanis masih mampu mempertahankan kekuatan fisiknya hingga usia 60-an. Penelitian terhadap usia 72-98 tahun menunjukkan bahwa latihan beban dapat meningkatkan kekuatan, massa otot dan mobilitas.

\section{Macam-macam Kekuatan}

Ditinjau dari sudut biomekanika kekuatan dapat dibedakan menjadi dua bagian, yaitu kekuatan dalam dan kekuatan dari luar. Kekuatan dalam

MEDIKORA Vol.III, No 1, April 2007:80-101 
adalah kekuatan otot, sedangkan kekuatan luar adalah kekuatan akibat gravitasi, dorongan angin, resistensi air atau gesekan tanah (Nossek, 1982: 20).

Bossey (1980: 24) membagi kekuatan otot menjadi tiga kelompok, yaitu:

1. Kekuatan statis (static strength) yang didefinisikan sebagai kemampuan untuk menggunakan tenaga maksimal selama periode singkat untuk melawan obyek yang tidak bisa dipindahkan. Juga dsebut isometric (metric berarti panjang, dan iso berarti sama, Isometric berarti sama panjang) atau gaya yang dilakukan tidak berjarak.

2. Kekuatan dinamis (dynamic strength) didefinisikan sebagai gerakan menahan beban secara berulang-ulang atau terus menerus dalam intensitas kerja sub maksimal, misalnya push-up

3. Kekuatan ledakan (explosive strength) didefinisikan sebagai kemampuan untuk menggunakan energi maximal dalam suatu ledakan, misalnya lompat jauh

Dalam kegiatan olahraga kompetisi, kekuatan dibagi menjadi kekuatan absolute dan kekuatan relative. Kekuatan absolute adalah kekuatan yang mampu dipindahkan oleh tubuh, sedangkan kekuatan relative adalah kekuatan maksimal yang dapat dipindahkan dibagi berat badan (Bompa, 2000: 234). 


\section{Tipe Latihan Kekuatan}

Latihan yang cocok untuk mengembangkan kekuatan adalah latihan tahanan (resistance training), yang dilakukan dengan cara mengangkat, mendorong atau menarik beban. Menurut Dreger (2006) latihan beban (weight training) adalah latihan yang dilakukan secara sistematis dengan menggunakan beban sebagai alat untuk menambah kekuatan otot guna memperbaiki kondisi fisik atlet, mencegah terjadinya cedera atau untuk tujuan kesehatan

Latihan beban dapat menggunakan beban berat badan sendiri, atau menggunakan beban bebas (free weight) seperti dumbell, barbell, atau mesin beban (gym machine) (Calhoon dan Fry, 1999:232). Latihan dengan beban berat badan sendiri lebih cocok untuk membina dayatahan dan kekuatan otot. Bentuk latihan yang banyak digunakan antara lain adalah: Chin-up, push-up, sit-up atau back-up. Sedangkan latihan menggunakan beban bebas lebih cocok untuk peserta yang sudah berpengalaman. Latihan beban dengan beban bebas dapat memudahkan atlet (peserta latihan) untuk mencapai kekuatan otot.

\section{Prinsip-prinsip Latihan Kekuatan}

Program latihan beban yang baik harus disusun dengan memperhatikan prinsip-prinsip latihan. Prinsip adalah semacam ketentuan yang harus dipedomani dalam membuat program latihan. Prinsip-prinsip latihan menurut Bompa (1994:75) adalah sebagai berikut :

MEDIKORA Vol.III, No 1, April 2007:80-101 


\section{1) Prinsip beban berlebih (Overload)}

Prinsip beban berlebih pada dasarnya menekankan beban kerja yang dijalani harus melebihi kemampuan yang dimiliki, karena itu beban latihan harus mencapai ambang rangsang. Hal ini bertujuan untuk merangsang penyesuaian fisiologis dalam tubuh sehingga akan mendorong meningkatnya kemampuan otot. Latihan yang menggunakan beban dibawah atau sama dengan kemampuannya, hanya akan menjaga kekuatan otot tetap stabil, tanpa diikuti peningkatan kekuatan. Prinsip overload ini dapat diperjelas dengan gambar 5 di bawah ini (Bompa, 2000:16) sebagai berikut.

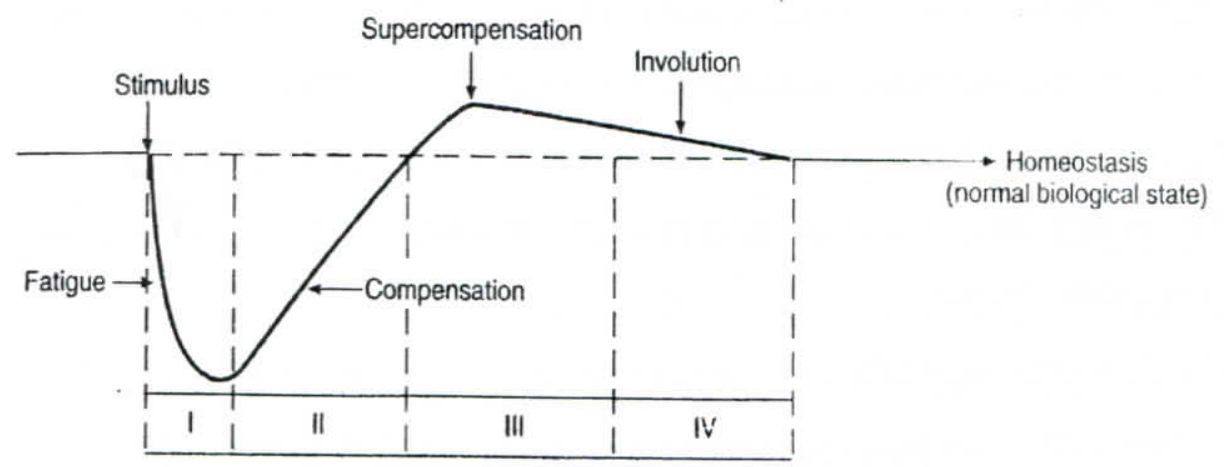

Gambar 5. Superkompensasi (Bompa, 2000: 16)

\section{2) Prinsip Peningkatan Secara Progresif}

Prinsip beban progresif dapat dilakukan dengan meningkatkan beban secara bertahap dalam suatu program latihan. Bila telah terjadi adaptasi latihan, maka beban yang berat akan terasa ringan. Karena itu pembebanan terhadap otot yang bekerja harus ditambah secara bertahap selama program latihan beban berjalan. Periode adaptasi organisme terhadap serentetan beban yang lebih tinggi selesai dalam waktu yang berbeda, paling 
tidak dua minggu (Nossek, 1982: 49). Menurut Kreamer dkk (2000: 626) latihan kekuatan akan nampak peningkatannya setelah 7 sampai 14 minggu. Suatu latihan yang tidak mempertimbangkan kenaikan beban secara progresif membuat prestasi berjalan stagnasi. Jika beban secara bertahap dinaikkan, maka olahragawan tersebut belajar menghabiskan tenaga yang dimiliki. Peningkatan beban dapat dilakukan dengan cara menambah repetisi, menambah set, memperpendek waktu pemulihan atau menambah frekuensi (Nossek, 1982: 50).

\section{3) Prinsip Berkebalikan (Reversibilitas)}

Kemampuan otot yang telah dicapai akan berangsur-angsur menurun bahkan bisa hilang sama sekali, jika tidak latihan. Kualitas otot akan menurun kembali apabila tidak dilatih secara teratur dan kontinyu. Karena itu rutinitas latihan mempunyai peranan penting dalam menjaga kemampuan otot yang telah dicapai.

\section{4) Prinsip Pulih Asal (Recovery)}

Program latihan yang baik harus dicantumkan waktu pemulihan yang cukup. Dalam latihan beban waktu pemulihan antar set harus diperhatikan. Jika tidak diperhatikan, atlet akan mengalami kelelahan yang berat dan penampilannya akan menurun. Recovery bertujuan untuk menghasilkan kembali energi, dan membuang asam laktat yang menumpuk di otot dan darah.

MEDIKORA Vol.III, No 1, April 2007:80-101 


\section{Menyusun Program Latihan Kekuatan}

\section{Menentukan Berat Beban Latihan}

Berat beban atau intensitas latihan menunjuk pada massa atau ukuran berat dari beban yang digunakan dalam mengembangkan kemampuan otot. Untuk menentukan intensitas latihan yang akan digunakan untuk latihan setiap repetisi dapat ditentukan dengan dua cara, yaitu:1) berdasar jumlah repetisi yang harus diangkat (Repetition Maximum/RM) 2) berdasarkan persentase atas beban maksimum yang dapat diangkat 1 kali usaha (One Repetision Maximum/1RM), (Baechle dan Groves, 1997: 64). Cara-cara tersebut dapat dijelaskan sebagai berikut:

\section{a. Repetisi Maksimum (Repetition Maximum/RM)}

Cara menentukan beban latihan dengan berdasar repetisi maksimum adalah dilakukan dengan mengetahui kemampuan otot untuk melakukan pengulangan (repetisi) maksimum dalam mengangkat beban yang akan digunakan untuk latihan. Sebagai contoh, seorang atlet akan melatih daya tahan otot bisep, maka atlet tersebut harus mengangkat dumbel (alat yang ingin ia gunakan) sebanyak 12-20 kali/set. Cara ini dapat dilakukan dengan percobaan, misalnya atlet tersebut mampu mengangkat dumbel $5 \mathrm{~kg}$ diangkat sebanyak 16 kali ulangan. Maka beban latihan dapat digunakan sebagai beban latihan, yaitu mengangkat dumbel $5 \mathrm{~kg}$ sebanyak 16 kali setiap setnya. 


\section{b. Persentase Dari Kemampuan Maksimum (One Repetition Maximum/1 RM)}

Mencari beban 1 RM dilakukan dengan metode trial and error, mencoba mengangkat beban sampai angkatan terberat tidak dapat diangkat lagi. Bagi atlet remaja dan usia muda tidak dianjurkan mencari beban 1 RM dengan metode trial and error, karena otot-otot mereka belum kuat, sehingga dikawatirkan mudah cedera.

Selanjutnya untuk menentukan beban latihan dapat digunakan persentase dari beban 1 RM tersebut. Bompa (1994: 78) memberikan klasifikasi intensitas latihan berdasarkan presentase kemampuan maksimal seperti table 1 sebagai berikut:

Tabel 1. Intensitas latihan kekuatan otot (Bompa, 1994: 78)

\begin{tabular}{|c|c|c|}
\hline Nomor Intensitas & $\begin{array}{c}\text { Presentase dari Kemampuan } \\
\text { Maksimal }\end{array}$ & Intensitas \\
\hline 1 & $30-50 \%$ & Low \\
2 & $50-70 \%$ & Intermediate \\
3 & $70-80 \%$ & Medium \\
4 & $80-90 \%$ & Submaximum \\
5 & $90-100 \%$ & Maximum \\
6 & $100-105 \%$ & supermaxium \\
\hline
\end{tabular}

Contoh bila seorang atlet otot bisepnya dapat mengangkat dambel 20 kg sekali mengangkat, maka jika atlet tersebut ingin melatih kekuatan otot bisep dan ingin menggunakan beban $80 \%$ dari 1 RM, maka beban latihan harus menggunakan dumbel seberat $80 \% \times 20 \mathrm{~kg}=16 \mathrm{~kg}$.

MEDI KORA Vol.III, No 1, April 2007:80-101 


\section{Menentukan Set, Repetisi dan Recovery}

Satu set latihan terdiri dari sejumlah repetisi (ulangan) latihan yang diikuti dengan interval istirahat. Beban, repetisi dan jumlah set latihan mempunyai hubungan yang terbalik. Jika beban dan repetisi meningkat, maka jumlah set latihan menjadi menurun. Jumlah set juga dipengaruhi oleh kemampuan atlet dan kelompok otot yang akan dilatih. Pelompat tinggi biasanya menggunakan latihan 3-5 set pada program awal, dan kemudian 610 set pada program spesialisasi. Sementara pegulat akan mengembangkan kelompok otot-ototnya dengan latihan 3-6 set. Secara umum 1 atihan yang baik berkisar antara 3-8 set (Bompa, 1994: 275).

Secara umum, cara terbaik membangun kekuatan adalah dengan mengangkat beban tiga set, yang terdiri 8-12 kali untuk setiap set (Satulelaki.com, 2004). Kombinasi jumlah set dan repetisi yang baik akan dapat meningkatkan kekuatan otot. Hal ini mengandung makna bahwa sebuah program latihan yang didisain dengan sistematis akan dapat meningkatkan kekuatan atlet. Bompa (1993:14) menyatakan bahwa latihan 5 set dengan 6 repetisi membangun kekuatan lebih cepat daripada latihan 3 set dengan 6 repetisi. Sementara Sprague (1993:73) menyatakan bahwa latihan beban 3 set dengan 6 repetisi cukup efisien untuk meningkatkan kekuatan. Lebih lanjut Sprague (1993:74) menganjurkan bagi atlet pemula atau lama tidak berlatihan sebaiknya berlatih dengan repetisi 12 kali setiap set. Selanjutnya setelah terjadi adaptasi, beban, repetisi dan set bisa ditambah sesuai perkembangan atlet. 
Interval istirahat (recovery) secara progesif menurun seirama dengan penyesuaian diri atlet terhadap rangsang latihan. Interval istirahat diperpanjang ketika beban meningkat. Interval istirahat juga tergantung pada tenaga yang dikerahkan, status latihan, irama dan durasi latihan, dan jumlah otot yang terlibat. Bompa (1994: 275-276) memberi petunjuk bahwa latihan yang bertujuan mengembangkan kekuatan maksimum, interval istirahat antara 2-5 menit. Untuk pengembangan dayatahan otot, interval istirahat pendek yaitu 1-2 menit, bahkan jika latihan dikemas dalam bentuk sirkuit dan dihubungkan dengan respon denyut nadi, maka ketika istirahat denyut nadi mencapai rata-rata $120 \mathrm{bpm}$, maka set berikutnya baru bisa dilakukan.

Kecermatan dalam memilih metode latihan dengan mempertimbangkan antara berat beban, set, repetisi, dan recovery akan sangat menentukan keberhasilan dalam membuat program latihan kekuatan.

Baechle dan Groves (1997: 192) juga membuat petunjuk latihan beban dengan mempertimbangkan tujuan latihan, berat beban, repetisi, set dan masa istirahat antar set seperti pada tabel 2 berikut ini.

Tabel 2. Parameter latihan beban (Baechle dan Groves, 1997: 192)

\begin{tabular}{|l|c|c|c|c|}
\hline \multicolumn{1}{|c|}{ Tujuan Latihan } & \% 1RM & Repetisi & Set & Istirahat antara set \\
\hline Kekuatan otot & $80-100$ & $1-8$ & $3-5$ & $2-5$ menit \\
\hline Data tahan otot & $<70$ & $12-20$ & $2-3$ & $20-30$ detik \\
\hline Hipertropi otot & $70-80$ & $8-12$ & $3-6$ & $30-90$ detik \\
\hline Pengencangan otot & $70-80$ & $12-15$ & $2-3$ & 30 detik \\
\hline
\end{tabular}

MEDIKORA Vol.III, No 1, April 2007:80-101 


\section{Repetisi dan Irama Angkatan}

Repetisi adalah jumlah ulangan yang dilakukan dalam mengangkat beban. Menurut Bompa (1994: 273) berat beban akan menentukan jumlah repetisi. Semakin berat beban semakin rendah jumlah repetisi. Lebih lanjut dinyatakan oleh Bompa (1994: 273) bahwa untuk pengembangan kekuatan maksimum memerlukan repetisi 1-3 ulangan dengan irama angkatan sangat rendah. Pengembangan power dengan repetisi 5-10 ulangan dengan irama angkatan dinamis. Untuk pengembangan dayatahan otot menggunakan repetisi banyak 10-30, bahkan bisa mencapai 250 ulangan dengan irama rendah hingga sedang.

\section{Pernafasan}

Mengatur pernafasan merupakan aktivitas penting yang terkadang diabaikan oleh atlet. Kecenderungan atlet adalah menahan nafas selama fase pengeluaran tenaga. Cara ini tidak benar, karena jika pengeluaran nafas dan ambilan oksigen tidak teratur akan berakibat pada kekurangan oksigen, sehingga pada gilirannya oksigen ke otak berkurang dan bisa menimbulkan rasa pusing, bahkan seorang atlet bisa tidak sadarkan diri.

Cara yang benar bernafas adalah pada saat mengangkat beban (bar misalnya) keluarkan nafas, terutama pada saat melewati bagian paling sukar dari fase pengangkatan itu. Contoh jika anda mengangkat bar setinggi lutut, maka titik pengangkatan tersukar adalah sedikit diatas lutut. Menarik nafas dilakukan pada saat menurunkan bar ke lantai. Jadi mengeluarkan nafas dilakukan pada saat mengeluarkan tanaga/ otot berkontraksi, dan menarik 
nafas pada saat mengendorkan otot (relaksasi) (Baechle dan Grovers, 2003: 49)

\section{Pengaturan Latihan}

Agar latihan bisa seimbang secara fisiologis, maka perlu dilakukan pengaturan latihan. Tiga pengaturan yang umum digunakan menurut Baechle dan Grovers (2003: 178) adalah:

a. Latihan-latihan kelompok otot besar terlebih dahulu. Sebuah contoh cara mengatur latihan dengan kelompok otot-otot besar seperti berikut:

\begin{tabular}{|l|l|l|}
\hline \multicolumn{1}{|c|}{ Latihan } & \multicolumn{1}{c|}{ Jenis Otot } & \multicolumn{1}{c|}{ Kelompok Otot } \\
\hline Lunge & Besar & Paha dan pinggul \\
\hline Heel Rise & Kecil & Betis \\
\hline Bench press & Besar & Dada \\
\hline Tricep extention & Kecil & Lengan (posterior) \\
\hline Lat pull down & Besar & Pungung atas \\
\hline Bicep curl & Kecil & Lengan (anterior) \\
\hline
\end{tabular}

b. Latihan-latihan mendorong dan menarik dilakukan secara bergantian. Sebuah contoh cara mengatur latihan- latihan dengan mendorong dan menarik sebagai berikut:

\begin{tabular}{|l|l|l|}
\hline \multicolumn{1}{|c|}{ Latihan } & \multicolumn{1}{c|}{ Jenis Latihan } & \multicolumn{1}{c|}{ Kelompok Otot } \\
\hline Bench press & Mendorong & Dada \\
\hline Lat pull down & Menarik & Punggung \\
\hline Seated press & Mendorong & Pundak \\
\hline Bicep curl & Menarik & Lengan (anterior) \\
\hline Tricep extention & Mendorong & Lengan (posterior) \\
\hline Leg curl & Menarik & Paha (anterior) \\
\hline Knee exention & Mendorong & Paha ((posterior) \\
\hline
\end{tabular}

MEDIKORA Vol.III, No 1, April 2007:80-101 
c. Latihan-latihan kelompok otot tubuh atas dan kelompok otot-otot tubuh bawah bergantian. Sebuah contoh cara mengatur latihanlatihan dengan kelompok otot-otot tubuh atas dan bawah sebagai berikut:

\begin{tabular}{|l|l|l|}
\hline \multicolumn{1}{|c|}{ Latihan } & \multicolumn{1}{c|}{ Jenis Latihan } & \multicolumn{1}{c|}{ Kelompok Otot } \\
\hline Bench press & Tubuh atas & Dada \\
\hline Lunge & Tubuh bawah & Paha dan pinggul \\
\hline Bicep curl & Tubuh atas & Lengan (anterior) \\
\hline Knee extention & Tubuh bawah & Paha (posterior) \\
\hline Standing press & Tubuh atas & Pundak \\
\hline Leg curl & Tubuh bawah & Paha (anterior) \\
\hline
\end{tabular}

\section{G. Syarat-syarat Latihan}

Sebelum suatu program latihan beban dijalankan terlebih dahulu seorang atlet harus menjalani serangkaian tes untuk mengetahui kondisi awal atlet. Tes tersebut terdiri dari: 1) Pemeriksaan kesehatan secara umum dan 2) Tes kemampuan fisik, misalnya kekuatan otot leg-press.

Pemeriksaan kesehatan secara umum, dimulai dengan tes penjajagan kesehatan (Adisapoetra, 1999: 71). Tes penjajagan kesehatan adalah tes yang berupa pertanyaan-pertanyaan tentang kondisi kesehatan peserta latihan. Pertanyaan-pertanyaan tersebut adalah sebagai berikut:

1). Apakah timbul rasa nyeri di bagian dada jika anda melakukan aktivitas fisik?

2). Bulan lalu apa ada rasa nyeri di dada ketika tidak melakukan latihan? 
3). Apakah anda pernah kehilangan keseimbangan karena pusing/tidak sadarkan diri?

4). Adakah masalah pada tulang/sendi menjadi lebih parah jika melakukan latihan?

5). Apakah anda mendapat perawatan dokter karena tekanan darah/kondisi jantung?

6). Apakah diketahui alasan yang melarang dilakukannya aktivitas fisik?

Jika dari pertanyaanp-pertanyaan tersebut ada jawaban "YA" periksakan ke dokter untuk memastikan boleh latihan atau tidak. Selain tes tersebut cobalah lakukan tes kesehatan yang paling mudah, seperti tes Denyut nadi, Tes Tekanan darah, pengukuran berat dan tinggi badan, serta melihat keadaan kesehatan fisik secara umum seperti postur tubuh.

\section{Fase Latihan}

Yang dimaksud fase latihan disini adalah tahapan atau urutan latihan yang harus diikuti oleh setiap atlet. Fase latihan tersebut terdiri dari pemanasan, latihan inti dan pendinginan

\section{Pemanasan}

Pada dasarnya pada bagian ini dimaksudkan untuk menyiapkan organisme atlet agar secara fisiologis dan psikologis siap menerima beban pada latihan inti. Gerakan pemanasan ini bertujuan mengulur otot ligamentum dan tendo agar memperbesar amplitudo dan memperkuat kontraksi otot, memperlancar peredaran darah dan meningkatkan suhu tubuh.

MEDIKORA Vol.III, No 1, April 2007:80-101 
Pemanasan dimulai dari gerakan dengan intensitas ringan semakin lama makin berat, dari gerakan sederhana menuju gerakan komplek. Pemanasan tidak boleh sampai melelahkan. Pemanasan untuk latihan biasanya lebih ringan dari latihan untuk pertandingan.

Urutan pemanasan dalam latihan beban adalah sebagai berikut:

1) Lakukan aktivitas aerobik dengan bersepeda statis kurang lebih 5 menit dengan beban ringan

2) Stretching statis dan stretching dinamis

Penguluran atau stretching dilakukan pada bagian tubuh yang selanjutnya akan dikenai laihan inti, misalnya peregangan pada tubuh bagian atas: peregangan pada dada, pereganan pada punggung samping, peregangan untuk bahu, peregangan untuk biceps, peregangan untuk triceps. Pereganan pada tubuh bagian bawah: Peregangan quadriceps, peregangan hamstring, peregangan betis, peregangan pada groin/paha dalam. Pada awalnya lakukan stretching statis kemudian dilanjutkan stretching dinamis

3) Lakukan latihan dengan beban ringan

Pemanasan ini berisi latihan dengan cara mencoba menggunakan beban selama satu set dengan beban ringan yaitu 30\% dari 1RM

\section{Latihan inti}

Sebelum latihan inti dilakukan pastikan beban-beban latihan dipasang sesuai dengan beban yang telah diprogramkan. Pastikan juga bahwa alat-alat yang digunakan terjamin keamanannya. Selanjutnya lakukan latihan dengan sungguh-sunguh dengan mengatur pernafasan serta 
memperhatikan waktu recovery, repetisi, dan jumlah set sesuai program yang telah diputuskan. Lakukan gerakan dengan teknik yang benar dan kerjakan dengan penuh konsentrasi jangan sampai timbul cidera pada saat latihan.

\section{Penenangan}

Setelah selesai latihan inti selanjunya memasuki masa penenangan. Pada fase ini lakukan aktivitas ringan, seperti stretching, dan aktivitas relaksasi. Setelah itu pelatih harus memberi evaluasi atas kegiatan latihan yang baru saja dilakukan.

\section{Penutup}

Dari uraian tersebut diatas, maka dapat ditarik kesimpulan sebagai berikut:

1. Latihan yang cocok untuk mengembangkan kekuatan otot adalah dengan latihan beban, yaitu dengan menangkat, mendorong, dan menarik (latihan isotonic)

2. Latihan didahului dengan pemanasan menyeluruh, kemudian diikuti mengangkat beban ringan

3. Menerapkan prinsip overload. Prinsip ini merupakan prinsip dominant yang akan menentukan hasil latihan

4. Repetisi antara 8-12 RM untuk setiap latihan. Setiap latihan dilakukan selama 3 set, dengan istirahat antar set 2-5 menit

5. Agar perkembangan otot tidak berat sebelah pilihlah latihan dengan memilih gerakan untuk otot agonis dan untuk antagonis.

MEDIKORA Vol.III, No 1, April 2007:80-101 
6. Perhatikan cara pernafasan. Keluarkan nafas pada saat mengangkat beban, dan mengambil nafas pada saat menurunkan beban.

7. Pilih dan lakukan gerakan dengan benar

8. Latihan dilakukan 3 kali dalam satu minggu, dengan diselingi satu hari istirahat.

9. Setiap kali latihan sebaiknya tidak lebih dari 12 bentuk latihan

10. Setiap akhir sesi latihan diakhiri dengan latihan peregangan statis dan relaksasi.

\section{Daftar Pustaka}

Adisapoetra, I.Z., dkk. 1999. Panduan Teknis Tes dan Latihan Kesegaran Jasmani untuk Atlet. Seminar dan Widiakarya nasional. Jakarta: Pengkajian dan Pengembangan IPTEK Olahraga Kamenegpora.

Baechle, T.R dan Groves, B.R. 1997. Weight Training: Steps to Success. Alih bahasa Latihan Beban oleh: Razi Siregar. Jakarta: PT. Raja Grafindo Persada.

Bompa, T.O. 1993. Periodization of Strength. New Wave in Strength Training. Toronto: Veritas Publishing Inc.

Bompa, T.O. 1994. Theory and Mrthodology of Training: The Key to Athlettics Performance. Dubuque: Kendal/ Hunt Publishing Company.

Bompa, T.O. 2000. Periodization, Theory and Methodology of Training. $4^{\text {th }}$ ed. Dubuque: Kendall/ Hunt Publishing Company. 
Bossey, D. 1980. The Jump: Conditioning and Technical Training. Victoria, Australia: Beatrice Publishing Pty, Ltd.

Calhoon, G., Fry, A.C. 1999. Injury Rates and Profiles of Elite Competitive Weightlifters. Journal of Athletic Training. Vol.34 (3), pp. 232-238.

Dreger, R.W. 2006. Strength Training Consideration for Youth. Edmonton, Alberta: The Northern Alberta Institute of Tecnology.

Fox, E.L. 1984. Human Physiology. $4^{\text {the }}$. Lowa Wm. Brown Publisher Company.

Kent, M. 1994. The Oxford Dictionary ofSport Scince and Medicine. New York: Oxford Univercity Press.

Kreamer WJ, Ratamess N, Fry AC, McBride TT, Koziris LP, Bauer JA, Lynch JM, Fleck SJ. 2000. Influence of Resistance Training Volume and Periodezation on Physiological and Performance Adaptation in Collegiate Women Tennis Players. Journal of Sport Med.Vol.28, pp. 626-641

Nossek, J. 1982. General Theory of Training. Lagos: National Institut for Sport, Pan African Press Ltd.

Pearl, B., Moran, G.T. 1986. Weight Training Men and Women, Getting Stronger. California: Shelter Publication Inc.

Sharkey, B.J 2003. Fitness And Health. Alih bahasa Kebugaran dan Kesehatan oleh: Eri Desmarini Nasution. Jakarta: PT. Raja Grafindo Persada.

Satulelaki.com./cetak/0\%2C51442COO.htm/2004.Latihan Kekuatan, Tingkatkan Kepercayaan Diri.

Sprague, K. 1993. Sport Strength. New York. The Putnam Publishing Group.

Wilmore JH., Costill DL. 1994. Physiology of Sport and Exercise, USA: Human Kinetics.

MEDIKORA Vol.III, No 1, April 2007:80-101 